\title{
Magnesium Sulphate Attacks on Mortars - Influence of Temperature, Type of Sand and Type of Cement
}

\author{
M.N Aziez* and A. Bezzar
}

Laboratory EOLE, University of Tlemcen, BP 230, Chetouan, Algeria

Received 26 November 2016; Accepted 27 January 2017

\begin{abstract}
In this paper, an experimental study describing the coupling between temperature and external sulphate attacks on cementitious materials is performed. Cubic mortar specimens made of three types of cement, and two types of sand, i.e. silica sand and limestone sand. The mortars prepared, were then immersed in a 5\% MgSO4 solution, at 5, 20 and $50{ }^{\circ} \mathrm{C}$, for 12 months. No damage was observed on the samples exposed to the sulphate solution at 20 , and $50{ }^{\circ} \mathrm{C}$. However, serious damage was noted on mortars made with silica sand exposed to the previous solution at $5{ }^{\circ} \mathrm{C}$. Moreover, XRD traces indicated that the formation of thaumasite and ettringite are responsible for the sulfate deterioration of mortars. The samples with limestone sand, at various temperatures; they showed better resistance against sulphate attacks compared to samples with silica sand. The results show that magnesium sulphate attacks at low temperatures are much faster than high temperatures.
\end{abstract}

Keywords: temperature; magnesium sulfate attack, sand, Portland cement, thaumasite, mortar.

\section{Introduction}

External sulfate attacks (ESA) are among the causes of deterioration that affect the durability of concrete structures $[1,2]$; they are characterized by an expansion of the material, resulting from the formation of products, such as thaumasite, gypsum and ettringite. These substances create internal tensile stresses that lead to expansion of the material and cracks on its surface. They increase the material's permeability, and promote debonding and alteration of its mechanical properties [3, 4].

In Algeria, the problem of sulphate attack is obvious; particularly structures in the Southeast regions of the country. These structures are suffering, from many years, from the problem of high concentration of sulphate caused by the increased level of groundwater. The underground water in gypsum soils is widespread in Algeria, $7966.3 \mathrm{~km}^{2}$. It represents $12 \%$ of gypsum soils in the world, as ranked by (FAO, 1990) [5]. The majority of structures built in these regions use natural silica sand from M'zi river, in the town of Laghouat. However, sand extraction in an uncontrolled and abusive manner has become a serious aggression against the environment [6].

In recent years, and for ecological and economic reasons, there has been a remarkable growth in the use of cements with mineral additives, but the mechanisms of degradation of these cements are very complicated due to external sulphate attacks. Firstly, when mineral mixtures are present in cement, they significantly reduce $\mathrm{C}_{3} \mathrm{~A}$ (dilution effect) [7], and react with portlandite $(\mathrm{CH})$ to generate calcium silicate hydrate (C-S-H); they promote densification, and

\footnotetext{
E-mail address: aziez.mednadjib@yahoo.fr

ISSN: $1791-2377$ @ 2017 Eastern Macedonia and Thrace Institute of Technology. All rights reserved.
}

lower permeability [8]. On the other hand, in a magnesium sulfate attack, researchers showed that $\mathrm{Mg}^{+2}$ ions cause decalcification of C-S-H and turn into magnesium silicate hydrates (M-S-H) [9]. In this case, the presence of portlandite $(\mathrm{CH})$ may be beneficial because it would delay the action of magnesium ions, by trapping them in the form of brucite $[10,11]$.

Several researchers have studied the correlation between temperature and the rate of deterioration due to external sulphate attacks. They found out that degradation would be quick when the temperature of exposure to a sulfate solution decreases $[12,13]$. Besides, a strong relation was observed between thaumasite formation and low temperature. However, Akoz et al. [14] noted that high temperature (40 ${ }^{\circ} \mathrm{C}$ ) improves the compressive strength of mortars, reduces the diffusion rate of sulfate ions and decreases capillarity. Other researchers reported contradictory findings. Santhanam et al. [15] found that high temperatures cause rapid deterioration of materials. Felekogolu [16] concluded that the impact of temperature on compressive strength and expansion depends on the type of cations present in the solution and on the properties of cement as well.

The formation of thaumasite $\left(\mathrm{CaSiO}_{3} \cdot \mathrm{CaCO}_{3} \cdot \mathrm{CaSO}_{4} \cdot 15 \mathrm{H}_{2} \mathrm{O}\right)$ is the result of sulfate attack at low temperature. Thaumasite formation requires a source of calcium silicate, sulfate and carbonate ions, excess humidity and low temperature [17]. Very few studies, investigating the effect of the kind of sand on external sulfate attacks, have been carried out. The characteristics of the cement paste-aggregate interfacial transition zone (ITZ) depend on the type of sand used in the sample. This zone may provide materials with high porosities and permeabilities, therefore accelerating the penetration of sulfate ions [18]. Sands themselves, with their mineralogical 
compositions, can be another triggering source of sulphatic attack, called thaumasite sulfate attack (TSA) [19].

This paper describes an experimental study conducted on mortars exposed to sulphate solutions, at 5,20 , and $50{ }^{\circ} \mathrm{C}$ for 12 months. These mortars were made by varying the nature of cement firstly and the nature of sand (silica or limestone) secondly.

\section{Materials and experimental procedures}

\subsection{Materials}

\subsubsection{Cement}

Three types of cement were used in the preparation of mortars investigated here:

CEM I 42.5 sulphate resistant Portland cement (SRPC),

CEM II/A 42.5 portland slag cement (PSC),

CEM II/A 42.5 pozzolan-based Portland cement (PPC),

The chemical and mineralogical properties of the cements are shown in Table 1.

Table 1. Physical and Chemical Properties of cements.

\begin{tabular}{|c|c|c|c|}
\hline $\begin{array}{l}\text { Chemical } \\
\text { composition (\%) }\end{array}$ & PPC & PSC & SRPC \\
\hline 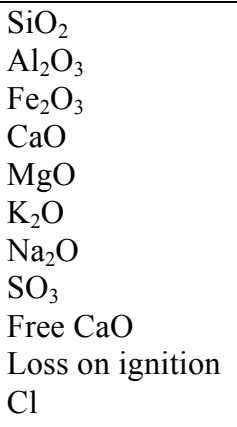 & $\begin{array}{l}27.17 \\
5.47 \\
3.17 \\
57.2 \\
1.01 \\
0.43 \\
0.3 \\
2.27 \\
0.9 \\
1.91 \\
0.006\end{array}$ & $\begin{array}{l}23.25 \\
5.69 \\
3.36 \\
60.24 \\
0.74 \\
0.45 \\
0.27 \\
1.94 \\
0.98 \\
1.67 \\
0.006\end{array}$ & $\begin{array}{l}19.28 \\
3.93 \\
4.75 \\
63.5 \\
0.96 \\
0.42 \\
0.13 \\
1.57 \\
1.07 \\
2.5 \\
0.02\end{array}$ \\
\hline $\begin{array}{l}\text { Clinkermineralo } \\
\text { gy }(\%)\end{array}$ & $\begin{array}{l}\mathrm{C}_{3} \mathrm{~S}=52.63 \\
\mathrm{C}_{2} \mathrm{~S}=23.68 \\
\mathrm{C}_{3} \mathrm{~A}=8.66 \\
\mathrm{C}_{4} \mathrm{AF}=10.7 \\
1\end{array}$ & $\begin{array}{l}\mathrm{C}_{3} \mathrm{~S}=59.66 \\
\mathrm{C}_{2} \mathrm{~S}=16.45 \\
\mathrm{C}_{3} \mathrm{~A}=9.14 \\
\mathrm{C}_{4} \mathrm{AF}=11.0 \\
2\end{array}$ & $\begin{array}{l}\mathrm{C}_{3} \mathrm{~S}=64.71 \\
\mathrm{C}_{2} \mathrm{~S}=15 \\
\mathrm{C}_{3} \mathrm{~A}=2.38 \\
\mathrm{C}_{4} \mathrm{AF}=14.4 \\
5\end{array}$ \\
\hline
\end{tabular}

\subsubsection{Sands}

The sands used in this study are of two different kinds. The first one is natural silica sand from the area of the river of M'zi (Laghouat); the second is limestone sand from the National Company of Aggregates. The physical characteristics of the two types of sand are reported in Table 2

\subsection{Experimental program}

The mortar specimens were prepared with three types of cement and two types of sand, according to standard EN $196-1$, with a $\mathrm{W} / \mathrm{C}$ ratio $=0.5$ and $\mathrm{C} / \mathrm{S}$ ratio $=1 / 3$. The cubeshaped samples, with $40 \mathrm{~mm}$ on a side, were chosen to accelerate the degradation process [20]. After preparation, the samples were left in their molds, for 24 hours. Next, they were put in water for one month, at the temperature $\mathrm{T}=20 \pm$ $3{ }^{\circ} \mathrm{C}$. Then the cubic samples were immersed into the $5 \%$ $\mathrm{MgSO}_{4}$ solution, for 12 months at 5,20 , and $50{ }^{\circ} \mathrm{C}$. The ratio of liquid (sulphate solution) to solid (mortar) was constant, and kept equal to about 4.5. In the different tests, the solutions were renewed every three months. The mortar samples containing silica sand were labelled XXX-s (e.g. PPC-s), while those containing limestone sand are XXX-c (e.g. PPC-c).

Table 2. Physical properties of sands used.

\begin{tabular}{|c|c|c|c|}
\hline $\begin{array}{l}\text { Physical } \\
\text { characteristics }\end{array}$ & Standard & $\begin{array}{l}\text { Siliceouse } \\
\text { sand }\end{array}$ & $\begin{array}{l}\text { Calcareouse } \\
\text { sand }\end{array}$ \\
\hline $\begin{array}{l}\text { Specific density } \\
\left(\mathrm{g} / \mathrm{cm}^{3}\right)\end{array}$ & -- & 2.64 & 2.68 \\
\hline $\begin{array}{l}\text { Apparent density } \\
\left(\mathrm{g} / \mathrm{cm}^{3}\right)\end{array}$ & -- & 1.53 & 1.47 \\
\hline Fineness modulus & -- & 2.41 & 2.3 \\
\hline $\begin{array}{l}\text { Visuel sand } \\
\text { equivalent }(\%)\end{array}$ & $\begin{array}{l}\text { NF P 18- } \\
598\end{array}$ & 85 & 67.5 \\
\hline $\begin{array}{l}\text { Piston sand } \\
\text { equivalent (\%) }\end{array}$ & $\begin{array}{l}\text { NF P 18- } \\
598\end{array}$ & 88 & 70 \\
\hline $\begin{array}{l}\text { Absorption } \\
\text { coefficient (\%) }\end{array}$ & $\begin{array}{l}\text { NF P 18- } \\
555\end{array}$ & 0.56 & 1.65 \\
\hline
\end{tabular}

\section{Results}

\subsection{Visual inspection}

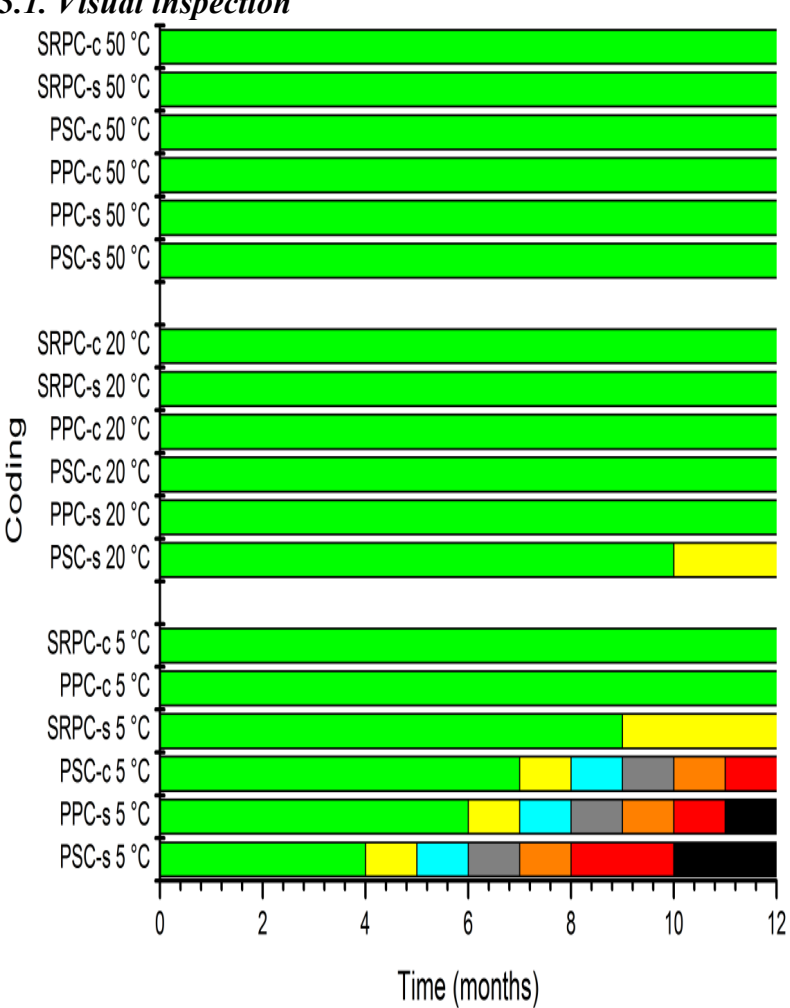

Fig. 1. Visual inspection of mortars immersed at 5,20 and $50{ }^{\circ} \mathrm{C}$ in $5 \%$ $\mathrm{MgSO}_{4}$ for 12 months. Colors were interpreted as follows: Green: no visible damage, Yellow: some deterioration in the corners, Cyan: some damage on the edges, Gray: damage on the corners and cracks along the edges, Orange: expansion in the corners and extensive cracks along the edges, Red: bursting of the surface, and Black: extensive spalling. 


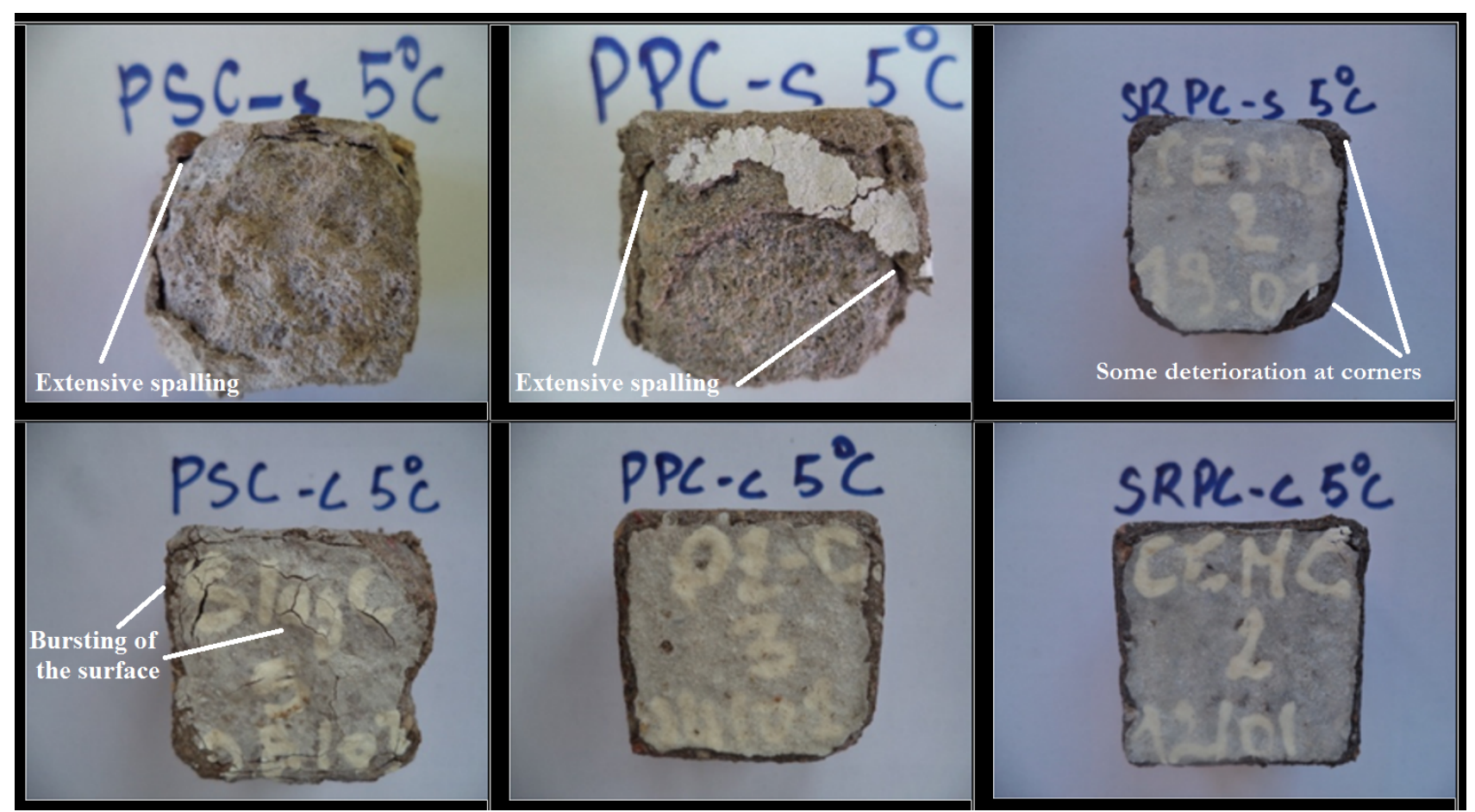

Fig. 2. Mortar samples after immersion in $5 \% \mathrm{MgSO}_{4}$ for 12 months at $5{ }^{\circ} \mathrm{C}$.

Monthly visual inspection of the samples was performed, after all significant changes. A visual inspection, to evaluate the degradation of the surface of mortar, was performed on the basis of color.

The visual inspection of the samples was performed on a monthly basis, and the observations are summarized in Figure 1. Figures 2 show the degree of degradation of the samples after 12 months of immersion at $5{ }^{\circ} \mathrm{C}$.

Figure 1 show the appearance of degradation appeared rapidly on samples PSC-s and PPC-s, which were kept in a sulphate solution, at $5{ }^{\circ} \mathrm{C}$. After 4 to 6 months of immersion, they showed the first signs of degradation, on the corners, followed by cracks along the edges, to finally break out after 8 to 12 months of exposure to the solution. Deterioration of sample PSC-c first appeared after 7 months, and at 12 months, the surface broke out. Mortar cubes with SRPC-s exhibited slight damage on the corners after 9 months, while no damage was recorded for samples PPC-c and SRPC-c, after 12 months of immersion. One should note that low temperatures $\left(5^{\circ} \mathrm{C}\right)$ accelerate the kinetics of degradation of all samples.

For mortars stored in magnesium sulfate at 20 and $50{ }^{\circ} \mathrm{C}$, no damage was observed for all samples. However, PSC-s showed a slight deterioration in the extremities, after 12 months of immersion at $20^{\circ} \mathrm{C}$.

In general, the first sign of attack is the degradation of the corners and edges of the cubic sample, along with the formation of a white layer on the top surface, followed by the appearance of cracks along the edges. Gradual expanding and bursting occurred on the specimen surface (see Figures 1 and 2). Mortars, exposed to sulfate attacks, during 12 months at 20 and $50{ }^{\circ} \mathrm{C}$, showed better resistance to sulfate attack than those stored at $5{ }^{\circ} \mathrm{C}$. In addition, the samples with limestone sand underwent less damage than those with silica sand.

\subsection{Mass changes}

Mass was measured on a monthly basis, with an OHAUS balance $(0.0001 \mathrm{~g}$ accuracy). The change in mass was calculated using the average of three values, according to equation (1):

Mass changes $(t)=\left(\left(M_{i}-M_{t}\right) / M_{i}\right) \times 100$

Where $t$ is time, $M_{i}$ the initial mass of mortar (reference mortar), $\mathrm{M}_{\mathrm{t}}$ is the mass at time $\mathrm{t}$ (time of exposure).

\subsubsection{Mass changes at $5^{\circ} \mathrm{C}$}

Figures 3 and 4 show the time variations of the mass of samples immersed in the $5{ }^{\circ} \mathrm{C}$ sulfate solution. Initially, all the samples made with the two types of sand (silica and limestone) showed a mass increase, followed by a decrease in certain other samples.

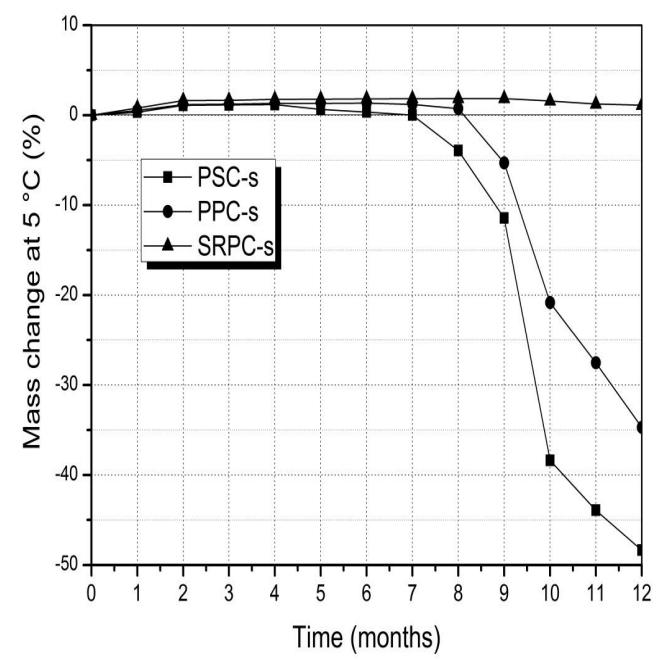

Fig. 3. Mass change of mortar samples with silica sand after immersion in $5 \% \mathrm{MgSO}_{4}$ for 12 months at $5{ }^{\circ} \mathrm{C}$. 


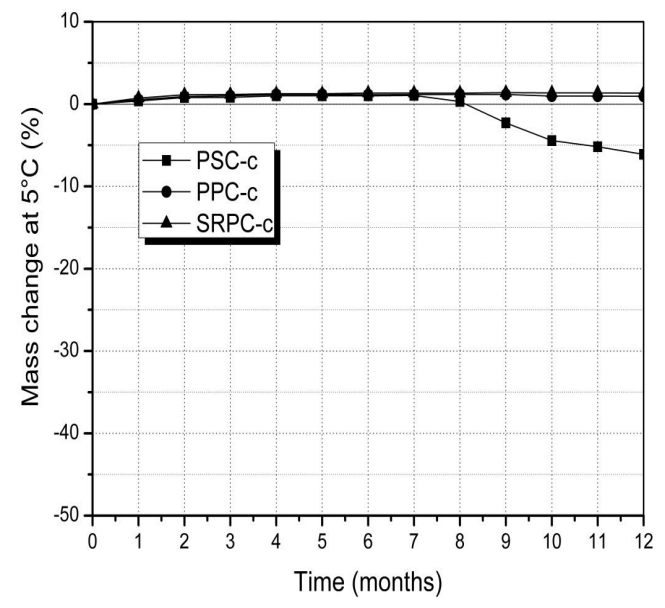

Fig. 4. Mass change of mortar samples with limestone sand after immersion in $5 \% \mathrm{MgSO}_{4}$ for 12 months at $5{ }^{\circ} \mathrm{C}$.

In the case of silica sand, PSC-s mortars presented a maximum mass increase of about $1.16 \%$, after 4 months to reach, after 8 months, a decrease of $3.93 \%$. A total mass loss of $48.35 \%$ was noted after 12 months of exposure to the sulfate solution at $5{ }^{\circ} \mathrm{C}$. Furthermore, PPC-s mortars showed a maximum mass increase of $1.33 \%$, after 6 months. Mass losses of 5.29 and $34.69 \%$ were found after 9 and 12 months of immersion, respectively. Samples SRPC-s showed the highest mass increase, of $1.85 \%$, after 9 months; no notable mass loss was reported after 12 months of immersion.

In the case of limestone sand, PSC-c mortar showed a mass increase of $1.04 \%$ after 7 months of immersion, followed by a decrease of $2.23 \%$ after 9 months, to ultimately reach $6.1 \%$, after 12 months of immersion. On the other hand, PPC-c and SRPC-c mortars exhibited a continuous mass gain, without any loss, of about 1.17 and $1.39 \%$, after 12 months of immersion, in magnesium sulfate.

\subsubsection{Mass changes at $20^{\circ} \mathrm{C}$}

The mass variation of the cubic samples in contact with the sulfate solution at $20^{\circ} \mathrm{C}$, are shown in Figures 5 and 6 . Most mortars with limestone sand showed a mass increase, unlike mortars with silica sand which showed a mass increase, followed by a slight decrease after 12 months.

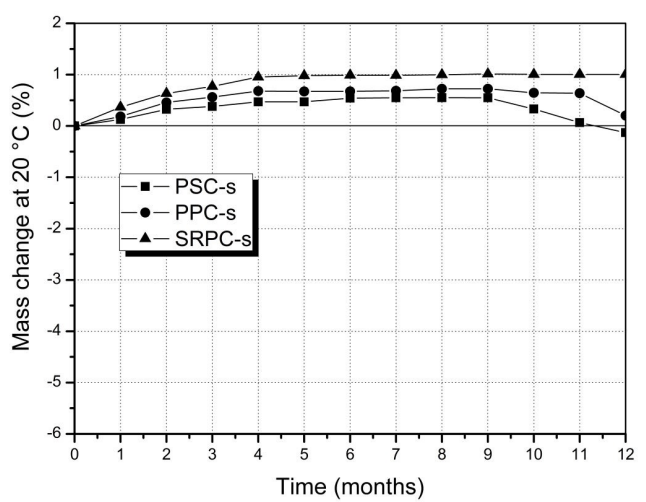

Fig. 5. Mass change of mortar samples with silica sand after immersion in $5 \% \mathrm{MgSO}_{4}$ for 12 months at $20^{\circ} \mathrm{C}$.

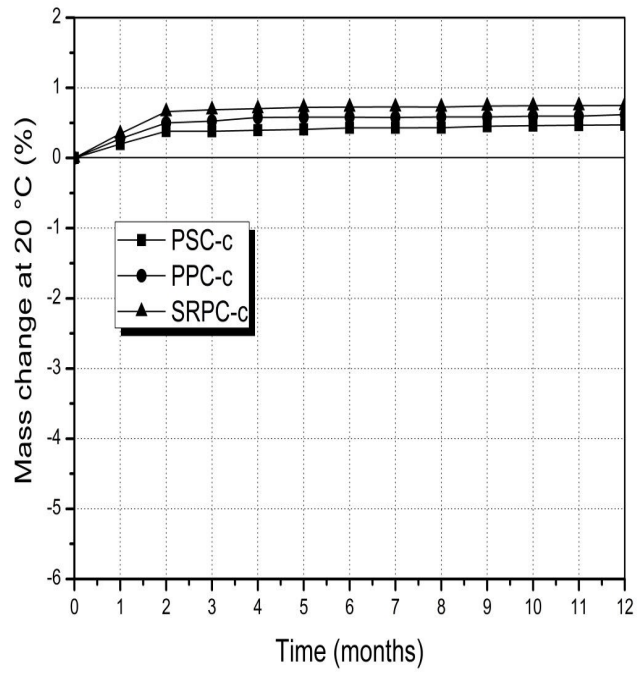

Fig. 6. Mass change of mortar samples with limestone sand after immersion in $5 \% \mathrm{MgSO}_{4}$ for 12 months at $20^{\circ} \mathrm{C}$.

Regarding silica sand (see Figure 5), mortars PSC-s and PPC-s showed a maximum mass increase of about 0.55 and $0.72 \%$, respectively, after 8 months of immersion. This was followed by a slight decrease near zero after 12 months.

In Figure 6, mortars with limestone sand show no loss. The samples PSC-c and PPC-c showed a maximum mass increase of the order of 0.46 and $0.59 \%$, respectively, after 12 months. SRPC-c mortars showed a final mass increase of the order of $0.74 \%$, after 12 months.

\subsubsection{Mass changes at $50{ }^{\circ} \mathrm{C}$}

The variations in the mass of samples exposed to the sulfate solution, at $50{ }^{\circ} \mathrm{C}$, as a function of exposure time, are shown in Figures 7 and 8 . These same figures show a continuous increase in the mass of mortar up to 12 months.

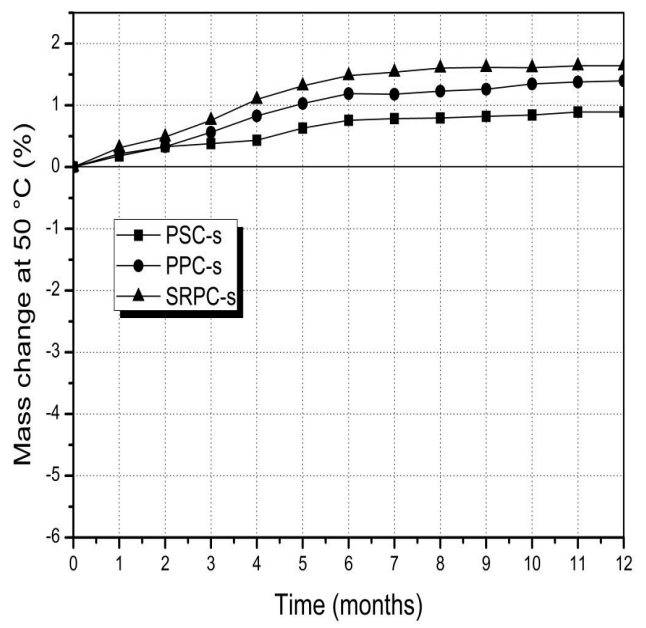

Fig. 7. Mass change of mortar samples with silica sand after immersion in $5 \% \mathrm{MgSO}_{4}$ for 12 months at $50{ }^{\circ} \mathrm{C}$.

Concerning silica sand (figure 7), the mass increase of PPC$\mathrm{s}$ and PSC-s mortars was less important than that of SRPC-s. After 12 months of immersion, the maximum mass increase 
recorded was $0.89,1.39$, and $1.64 \%$ for PSC-s, PPC-s, SRPC-s, respectively.

Regarding limestone sand, the PSC-c, PPC-c and SRPCc samples showed a continuous mass increase, to reach the maximum values of $0.92,1.4$, and $1.7 \%$, respectively, after 12 months (see figure 8).

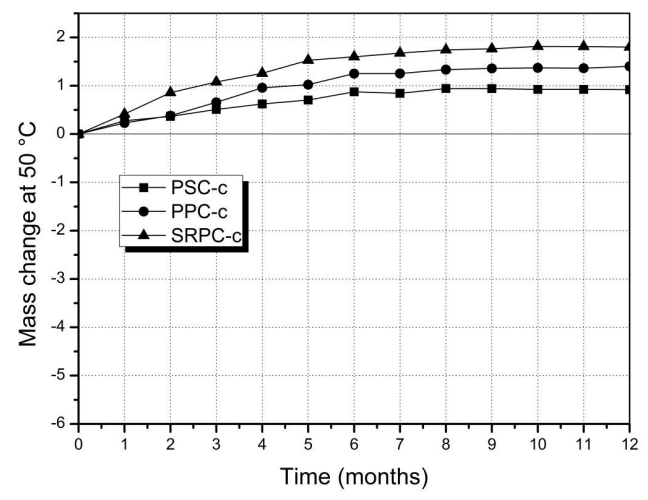

Fig. 8. Mass change of mortar samples with limestone sand after immersion in $5 \% \mathrm{MgSO}_{4}$ for 12 months at $50{ }^{\circ} \mathrm{C}$.

Note that the mass increase observed in the samples exposed to sulfates, at 20 and $50{ }^{\circ} \mathrm{C}$, was mainly due to the reactions between $\mathrm{Ca}(\mathrm{OH})_{2}$ and $\mathrm{MgSO}_{4}$ and two products were obtained, namely secondary gypsum $\mathrm{CaSO}_{4} \cdot 2 \mathrm{H}_{2} \mathrm{O}$ and brucite $\mathrm{Mg}(\mathrm{OH})_{2}$, which formed on the surface of samples [4].

\subsection{Compressive strength}

The compressive strength was calculated by averaging three measurements. This compressive strength was measured after one (01) month (strength of reference), and then after 2 , 4,6 , and 12 months of exposure to $5 \% \mathrm{MgSO}_{4}$ solution, at 5, 20 and $50{ }^{\circ} \mathrm{C}$.

\subsubsection{Compressive strength at $5{ }^{\circ} \mathrm{C}$}

Figure 9 shows the compressive strength's results of the samples, recorded after 1 month (reference strength), and then after 2, 4, 6, and 12 months of immersion in $5 \% \mathrm{MgSO}_{4}$ solution, at $5{ }^{\circ} \mathrm{C}$.

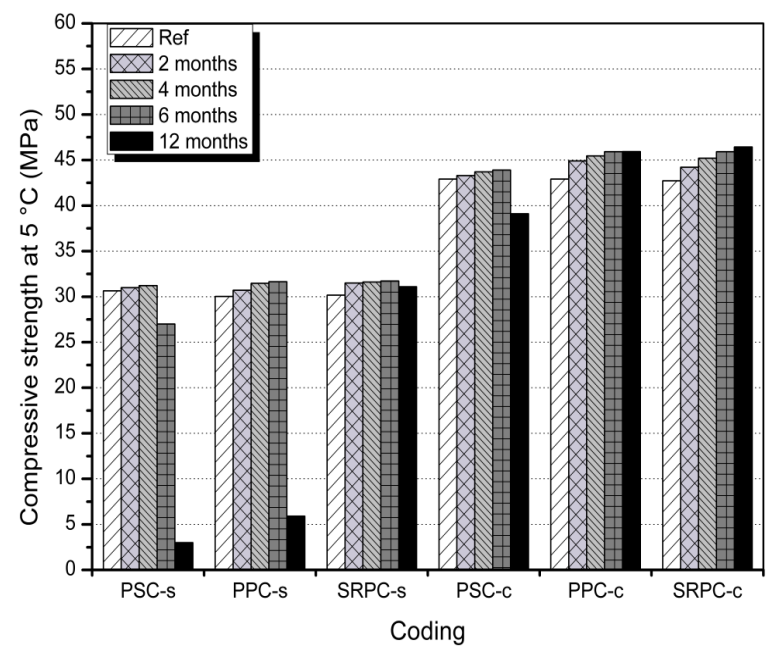

Fig. 9. Compressive strength of the mortars exposed in the solution of $5 \% \mathrm{MgSO}_{4}$ at $5{ }^{\circ} \mathrm{C}$.
In the case of silica sand, PSC-s mortars exhibited a slight increase in their compressive strength of approximately $2.85 \%$ after 4 months, followed by a decrease of about $11.85 \%$ after 6 months, to finally drop to the value of $79.59 \%$, after 12 months of immersion. Samples PPC-s showed a maximum increase in their strength of about $5.38 \%$ after 6 months of immersion, which then dropped to $54.91 \%$, after 12 months of immersion. SRPC-s mortars presented a strength rise about $3.08 \%$, after 12 months of immersion in the solution.

Regarding limestone sand, the compressive strength of PSC-c samples increased by about $2.33 \%$, after 6 months and then fell by $8.85 \%$, after 12 months. PPC-c and SRPCc samples, in turn, showed an increase in the compressive strength of the order of 7.08 and $8.63 \%$, respectively, after 12 months immersion.

\subsubsection{Compressive strength at $20^{\circ} \mathrm{C}$}

Figure 10 shows the results of the compressive strength of mortars, for 12 months of immersion in sulphate solution, at $20{ }^{\circ} \mathrm{C}$.

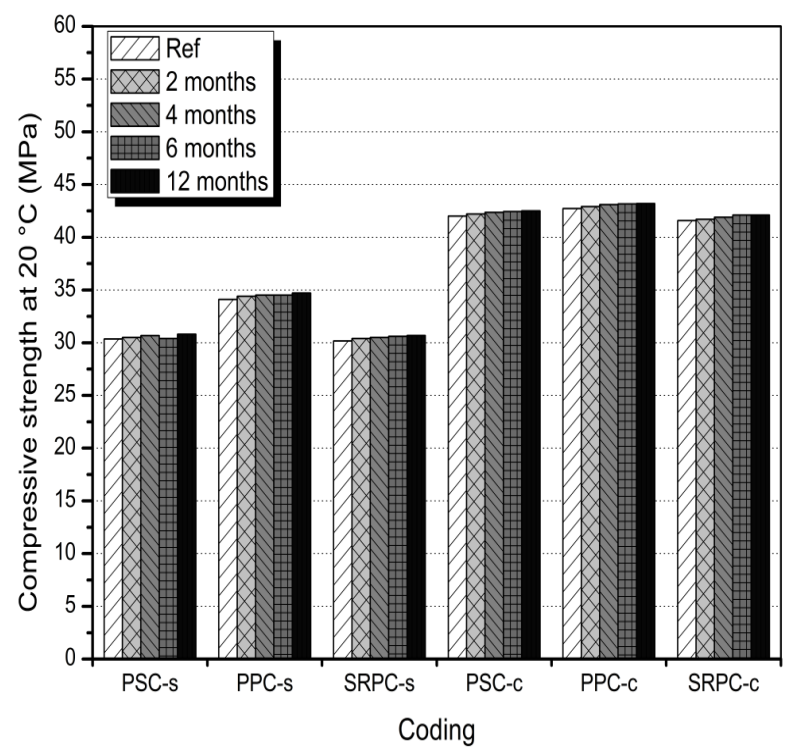

Fig. 10. Compressive strength of the mortars exposed in the solution of $5 \% \mathrm{MgSO}_{4}$ at $20^{\circ} \mathrm{C}$.

In the case of silica sand, the compressive strength of all mortars showed a continuous increase over 12 months. SRPC-s mortars in turn showed an increase in the compressive strength, of the order of 1.34 after 12 months. Mortars PPC-s and PSC-s observed a strength increase of about 1.75 and $1.51 \%$, respectively, after 12 months of immersion.

In the case of samples with limestone sand immersed in sulphate solutions, at $20{ }^{\circ} \mathrm{C}$, the mechanical strengths of mortars PSC-c, PPC-c and SRPC-c (see Figure 10) presented an increase in their compressive strength on the order of $1.19,1.09$ and $1.27 \%$, respectively, after 12 months of immersion.

\subsubsection{Compressive strength at $50{ }^{\circ} \mathrm{C}$}

Figure 11 shows the compressive strength of the samples immersed in the solution $5 \% \mathrm{MgSO}_{4}$, at $50{ }^{\circ} \mathrm{C}$. Mortars with silica sand exhibited a continuous increase in the compressive strength, up to 12 months. The increase in the compressive strength of mortars PPC-s and SRPC-s was 8.24 and $6.43 \%$, respectively; PSC-s reached a maximum 
value of $7.31 \%$, after 12 months of immersion in sulfate solution.

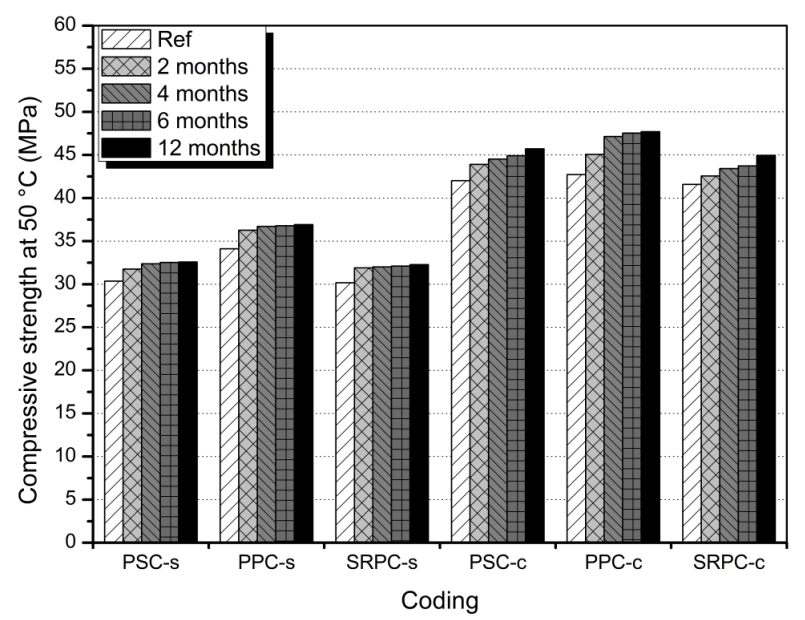

Fig. 11. Compressive strength of the mortars exposed in the solution of $5 \% \mathrm{MgSO}_{4}$ at $50{ }^{\circ} \mathrm{C}$.

The compressive strength of specimens containing limestone sand, showed a strength increase of the order of $11.60,8.8$ and $8.13 \%$, for mortars PPC-c, PSC-c and SRPCc, respectively, for 12 months of immersion. These results revealed the positive effect of slag and pozzolan in a sulphate medium, at high temperature $\left(50{ }^{\circ} \mathrm{C}\right)$. These findings are in good agreement with those of Akoz et al. [14] who obtained better mechanical properties in compression of Portland cement-based mortars into contact with sulfates, for 300 days, at $40{ }^{\circ} \mathrm{C}$.

\subsection{Ultrasonic pulse velocity}

The ultrasonic speed was varied at regular intervals, throughout the entire period of the test. Three cubic samples were used to measure the variation of the ultrasonic speed. The results given represent the average of three values.

\subsubsection{Ultrasonic pulse velocity at $5^{\circ} \mathrm{C}$}

The results of a series of ultrasonic pulse velocity tests, for the samples stored for 12 months in the $5 \% \mathrm{MgSO}_{4}$ solution at $5{ }^{\circ} \mathrm{C}$ are shown in Figure 12.

In the case of silica sand, the results confirm that PSC-s and PPC-s samples are the least resistant to external silicate attacks (ESA) at $5{ }^{\circ} \mathrm{C}$. The velocities dropped by about 84.73 and $78.59 \%$, respectively, after 12 months. However, the SRPC-s samples, with a low amount of $\mathrm{C}_{3} \mathrm{~A}$, showed a small decrease in velocity (around 6.25\%).

In the case of limestone sand, PSC-c sample showed the largest decrease in velocity, around $65.27 \%$, while in PPC-c mortars this decrease was approximately $14.84 \%$. Finally, SRPC-c registered a slight decline, about $1 \%$.

The results obtained show that the samples having undergone extensive damage, i.e. PSC-s and PPC-s, have also shown a decrease in the ultrasonic pulse velocity. This confirms the results found in the sections related to the loss of mass and compressive strength.

\subsubsection{Ultrasonic pulse velocity at 20 and $50^{\circ} \mathrm{C}$}

The results obtained on mortar samples stored for 12 months at 20 and $50{ }^{\circ} \mathrm{C}$ in a $5 \% \mathrm{MgSO}_{4}$ solution are shown in Figures 13 and 14.

The ultrasonic investigation showed that at the beginning of exposure to the sulfate solution, the speed increased slightly; this may be attributed to surface densification. At
$20{ }^{\circ} \mathrm{C}$, this velocity in sand-based mortars, PSC-s and PPC-s, beginning decreased slightly from 10 months. However, no decrease was noted, at $50{ }^{\circ} \mathrm{C}$.

The results obtained in Figures 12,13, and 14 showed that the samples that deteriorated most, i.e. PSC-s and PPC$\mathrm{s}$, showed a decrease in the ultrasonic pulse velocity as well. Note also the change in this velocity in the samples with no mass loss. This may be due to the change in their microstructure.

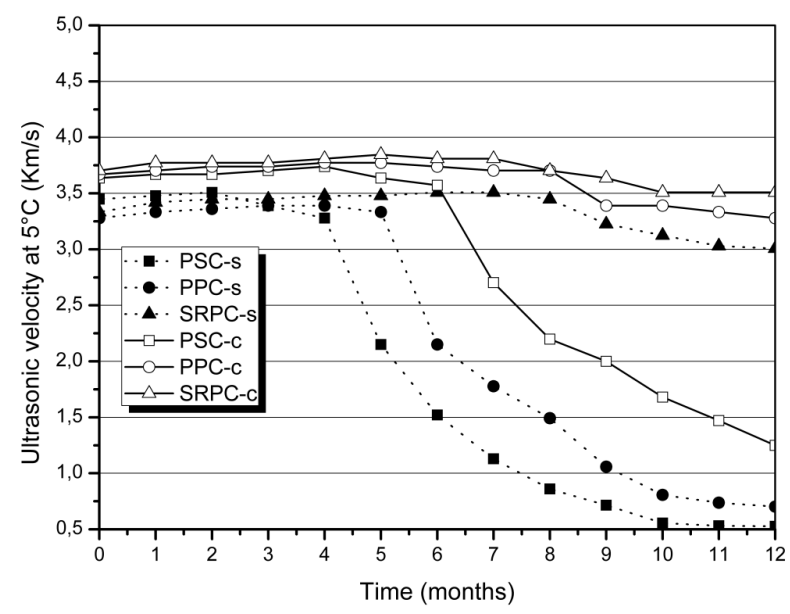

Fig. 12. Ultrasonic pulse velocity of specimens exposed in $5 \% \mathrm{MgSO}_{4}$ at $5{ }^{\circ} \mathrm{C}$ for 12 months.

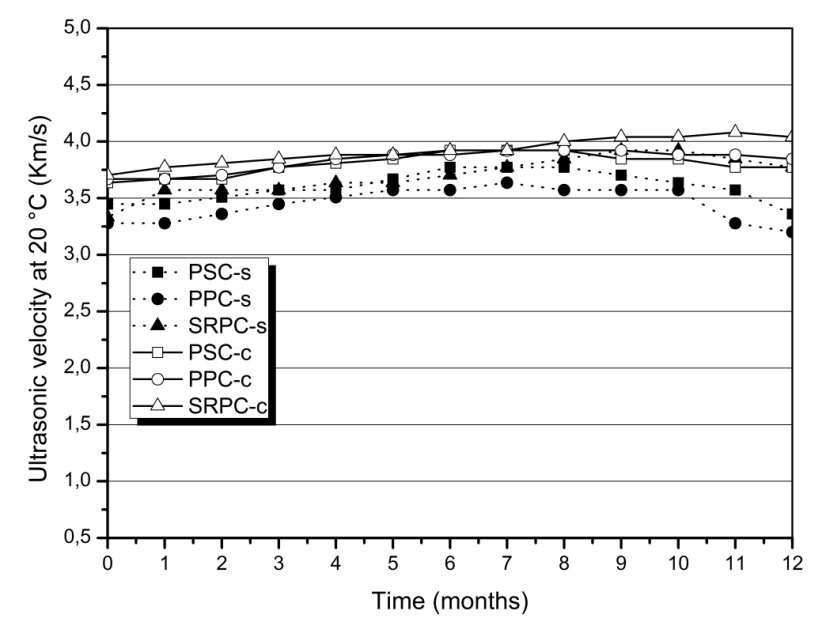

Fig. 13. Ultrasonic pulse velocity of specimens exposed in $5 \% \mathrm{MgSO}_{4}$ at $20^{\circ} \mathrm{C}$ for 12 months.

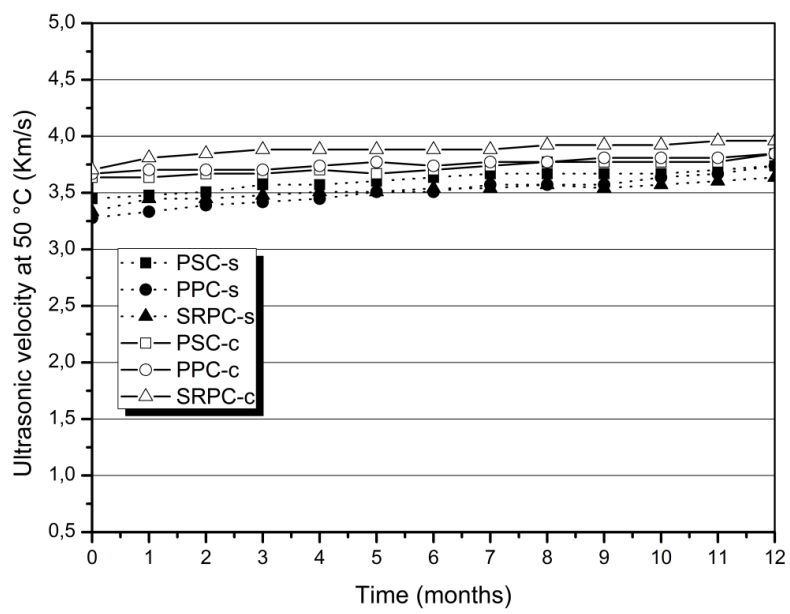

Fig. 14. Ultrasonic pulse velocity of specimens exposed in $5 \% \mathrm{MgSO}_{4}$ at $50{ }^{\circ} \mathrm{C}$ for 12 months. 


\subsection{Evolution of magnesium sulfate $\mathrm{pH}$}

The $\mathrm{pH}$ measurements were carried out with the kelp of an accurate digital device (OHAUS pH meter Starter 2000) equipped with a probe (ST210). The $\mathrm{pH}$ of the solutions was measured before each renewal of the solution (3 months).

Control of $\mathrm{pH}$ in sulfate solutions has been studied by several authors [21-23]. They found that the $\mathrm{pH}$ is an important factor in the aggressiveness toward concrete. When a cementitious material is placed in a magnesium sulfate solution (with $\mathrm{pH}$ between 7 and 8 ), this $\mathrm{pH}$ is found between 9 and 10, after a few minutes. This increase is due to the leaching of Portlandite [24].

A follow-up of the $\mathrm{pH}$ in the magnesium sulfate solution, at 5,20 and $50{ }^{\circ} \mathrm{C}$, was carried out before each renewal (3 months) of the solution, in order to monitor the $\mathrm{pH}$ until the end of the test. The obtained results are shown in Figures 15, 16 , and 17.

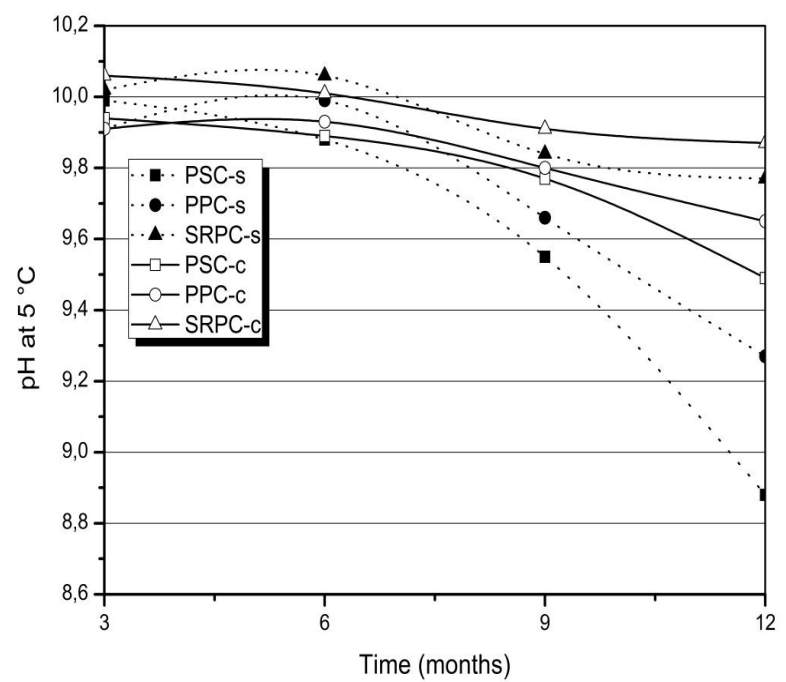

Fig. 15. Variation in $\mathrm{pH}$ magnesium sulphate solutions at $5{ }^{\circ} \mathrm{C}$ for 12 months.

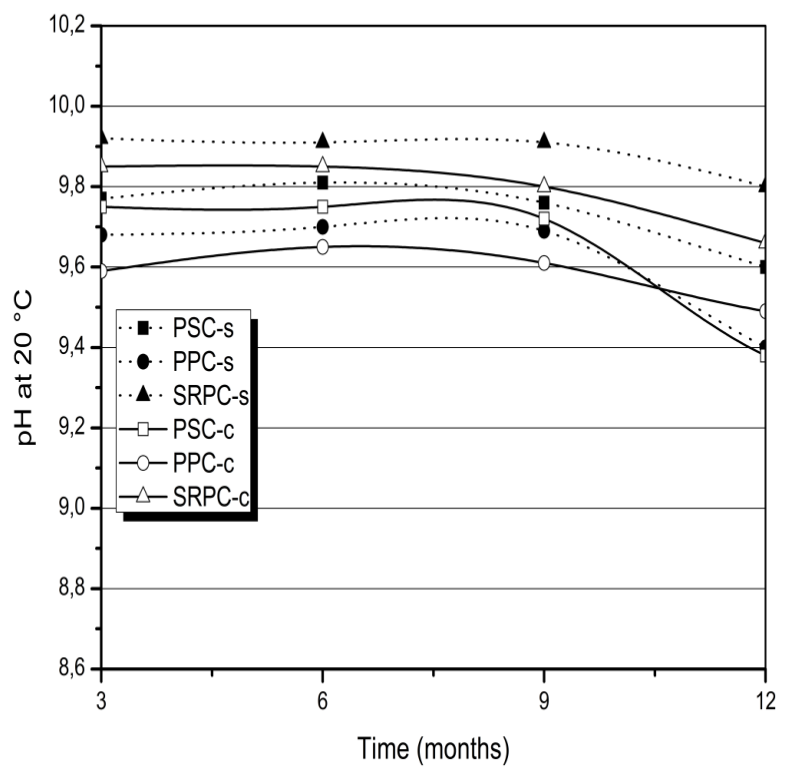

Fig. 16. Variation in $\mathrm{pH}$ magnesium sulphate solutions at $20^{\circ} \mathrm{C}$ for 12 months.

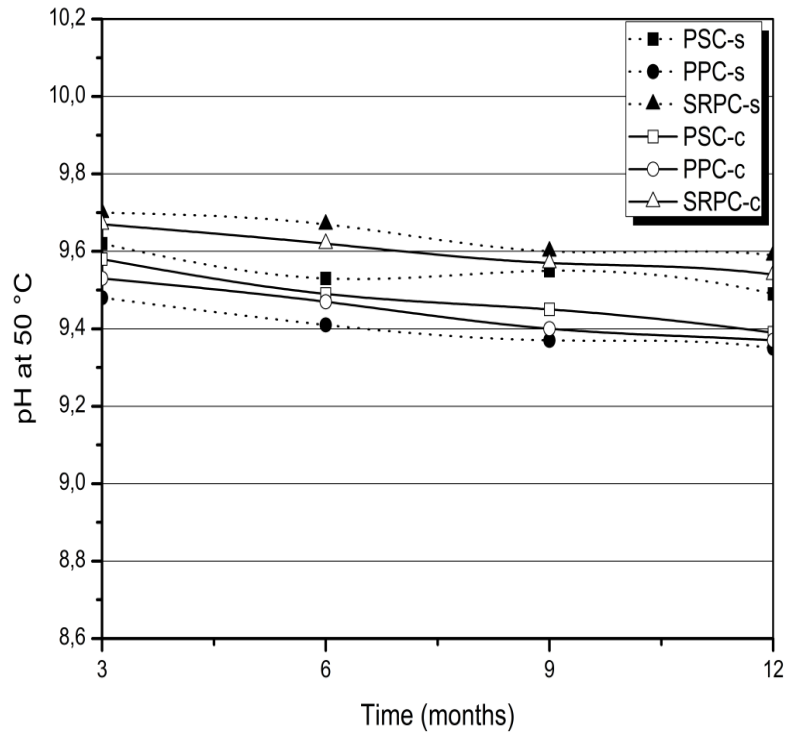

Fig. 17. Variation in $\mathrm{pH}$ magnesium sulphate solutions at $50{ }^{\circ} \mathrm{C}$ for 12 months.

A low Temperature, for samples containing SRPC (for both sand), the maximum $\mathrm{pH}$ values, 10.1 and 10.2 , were recorded at the first renewal of the solution; they then dropped to 9.8 and 9.9, respectively. The $\mathrm{pH}$ of PSC-s and PPC-s samples reached maximum values, between 9.9 and 10.0. After 12 months of immersion, the $\mathrm{pH}$ dropped to values between 8.88 and 9.27 (see Figure 15). The $\mathrm{pH}$ of the solution at low temperature plays an important role in the formation of products resulting from sulfate attacks (ESA). Authors Liu et al. [22] showed that in sulphate environments, with $\mathrm{pH}$ values around 10, gypsum may become a source for material degradation.

For samples immersed in $20{ }^{\circ} \mathrm{C}$ showed a slight decrease in the $\mathrm{pH}$ value, in the case of samples with SRPC, the maximum $\mathrm{pH}$ was found between 9.7 and 9.9. These values were recorded at the first renewal of the solution; these values were recorded at the first renewal of the solution; they remained almost stable at values between 9.8 and 9.6 at the end of the test (see Figure 16). At $20{ }^{\circ} \mathrm{C}$, the samples PSC-s and PPC-s showed a slight decrease in pH (9.4) after 12 months. The results obtained at $50^{\circ} \mathrm{C}$ showed that the $\mathrm{pH}$ in most of the samples is almost stable after 12 months.

Note also that the $\mathrm{pH}$ change depends more on the nature of cement than that of sand. This $\mathrm{pH}$ was found to be more important for cements without additions (SRPC); this is due to their high content in portlandite.

\subsection{X-ray diffraction analysis at $5^{\circ} \mathrm{C}$}

The XRD analyses were carried out on finely crushed samples ( $<80$ microns), collected from the surface of the degraded material. The mineralogical phases were identified with a PANalytical X'Pert PRO powder diffractometer, using a $\mathrm{Cu} \mathrm{K} \alpha$ radiation of wavelength $=1.54 \AA$, operating at $40 \mathrm{kV}$ and $30 \mathrm{~mA}$, with a step size $0.01^{\circ}(2 \theta)$, and a step time of $5 \mathrm{~s}$.

The mineralogical phases formed after immersion in the solution $5 \% \mathrm{MgSO}_{4}$, at $5{ }^{\circ} \mathrm{C}$, were determined with the help of the X-ray diffraction of powdery samples ( $<80$ microns), which had been obtained by grinding mortar extracts from the surface of degraded material, i.e. PSC-s, PPC-s, and PSC-c. The XRD diagrams presented in Figures 18, 19, and 20 shows that the main phases detected are ettringite, thaumasite, calcite, gypsum, quartz and some traces of 
brucite. It should be noted that no portlandite peak was detected. This is mainly due to the pozzolanic reactions that consume portlandite $(\mathrm{CH})$, and also to the probable reaction of $\mathrm{CH}$ with magnesium sulphate to form gypsum and brucite (see equation 2). Regarding the samples PSC-s, PPC-s and PSC-c, the largest peak of ettringite was found at $2 \theta=18.91$ ${ }^{\circ}$. All three mortars presented a gypsum peak at $2 \theta=28.2^{\circ}$. The other gypsum peaks coincide with some peaks of ettringite. This could be explained by the high concentration of sulfate solutions in the sample under consideration. The formation of gypsum may lead to expansion constraints. These findings are consistent with some studies which confirmed the expansive nature of gypsum $[25,26]$.

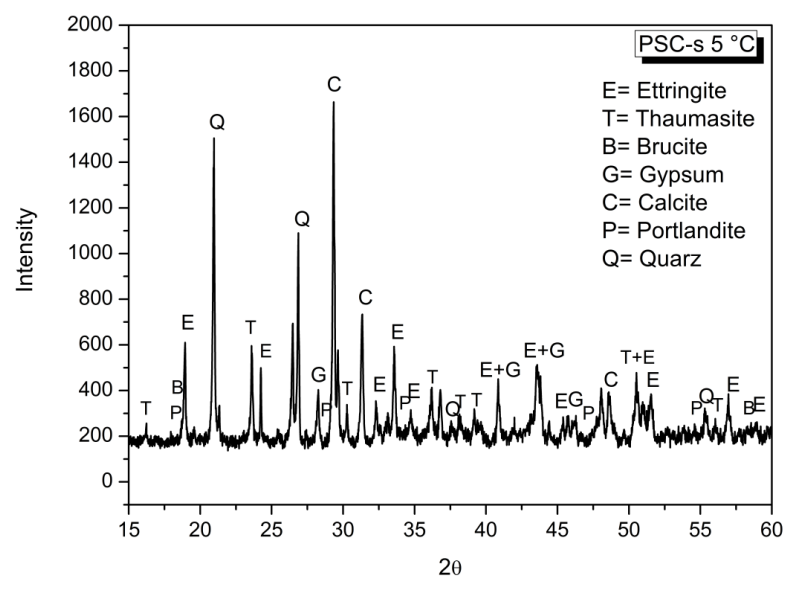

Fig. 18. X-ray diffraction of the PSC-s mortars after 10 months of exposure at $5^{\circ} \mathrm{C}$.

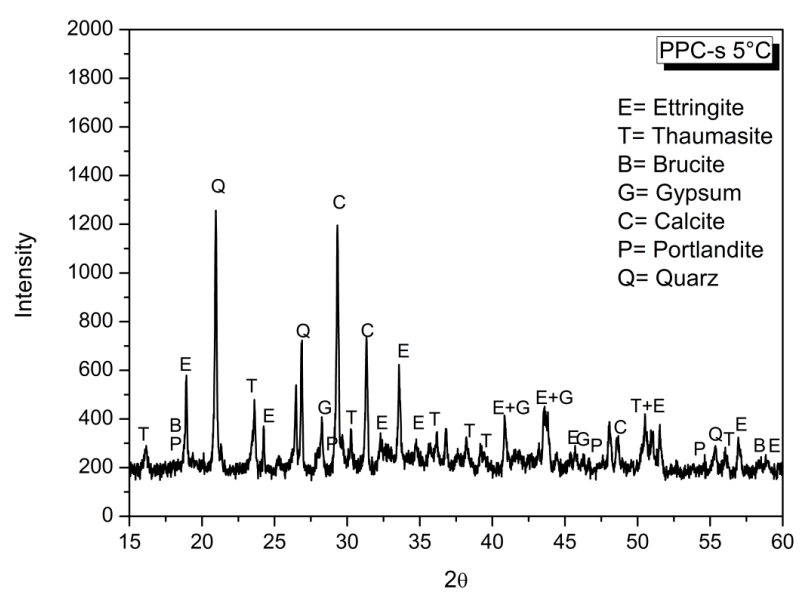

Fig. 19. X-ray diffraction of the PPC-s mortars after 11 months of exposure at $5^{\circ} \mathrm{C}$.

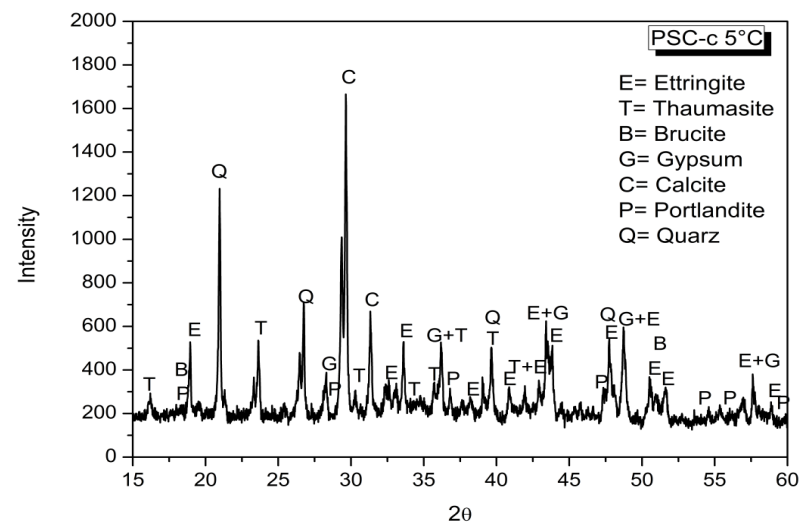

Fig. 20. X-ray diffraction of the PSC-c mortars after 12 months of exposure at $5^{\circ} \mathrm{C}$.
$\mathrm{Ca}(\mathrm{OH})_{2}+\mathrm{MgSO}_{4}+2 \mathrm{H}_{2} \mathrm{O} \rightarrow \mathrm{CaSO}_{4} \cdot 2 \mathrm{H}_{2} \mathrm{O}+\mathrm{Mg}(\mathrm{OH})_{2}$

(2)

In the second mechanism [27], secondary gypsum, resulting from reaction (2), reacts with tricalcium aluminate $\mathrm{C}_{3} \mathrm{~A}$, according to equation (3), to form secondary ettringite.

$3 \mathrm{CaO} \cdot \mathrm{Al}_{2} \mathrm{O}_{3}+3 \mathrm{CaSO}_{4} \cdot 2 \mathrm{H}_{2} \mathrm{O}+26 \mathrm{H}_{2} \mathrm{O} \rightarrow$
$3 \mathrm{CaO} \cdot \mathrm{Al}_{2} \mathrm{O}_{3} \cdot 3 \mathrm{CaSO}_{4} \cdot 32 \mathrm{H}_{2} \mathrm{O}$

Note that the major peaks of thaumasite are located at $2 \theta$ $=23.6^{\circ}$. The highest peak intensities of thaumasite are around 596, 497 and 536 for PSC-s, PPC-s and PSC-c, respectively. In addition, large calcite peaks were found in all samples at $2 \theta=29.4^{\circ}$. The intensities of the major peaks are respectively 1664, 1196 and 1660, for mortars PSC-s, PPC-s and PSC-c.

The formation of thaumasite could be achieved by two different mechanisms. In the first, it may be formed by a reaction between $\mathrm{C}-\mathrm{S}-\mathrm{H}$, gypsum, calcium carbonate and water $[28,29]$. This is known as the direct mechanism of thaumasite formation (Eq. 4).

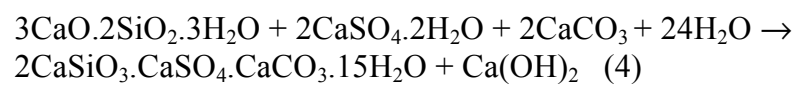

In the second mechanism, known as Woodfordite route, thaumasite formation results from a reaction between ettringite, $\mathrm{C}-\mathrm{S}-\mathrm{H}$ and carbonate ions in the presence of water (cf. eq. 5) [30].

$3 \mathrm{CaO} \cdot \mathrm{Al}_{2} \mathrm{O}_{3} \cdot 3 \mathrm{CaSO}_{4} \cdot 32 \mathrm{H}_{2} \mathrm{O}+3 \mathrm{CaO} \cdot 2 \mathrm{SiO}_{2} \cdot 3 \mathrm{H}_{2} \mathrm{O}+2 \mathrm{CaCO}_{3}$ $+4 \mathrm{H}_{2} \mathrm{O} \rightarrow 2 \mathrm{CaSiO}_{3} \cdot \mathrm{CaSO}_{4} \cdot \mathrm{CaCO}_{3} \cdot 15 \mathrm{H}_{2} \mathrm{O}+$

$\mathrm{CaSO}_{4} \cdot 2 \mathrm{H}_{2} \mathrm{O}+2 \mathrm{Al}(\mathrm{OH})_{3}+4 \mathrm{Ca}(\mathrm{OH})_{2}$

\section{Discussion}

\subsection{Influence of sand}

The results of our study indicate that mortars with limestone sand have better behavior vis-à-vis external sulfate attacks, compared to mortars with silica sand, particularly at low temperature due to the formation of thaumasite, although there is a glut of carbonate ions from limestone sand used (which are important sources for the outbreak of thaumasite sulfate attack), then we can see that the presence of fine particles (carbonates) from limestone sand is of minor importance, and probably the nature of the interface transition zone plays a major role in the resistance of cementitious materials against external sulfate attacks. This is certainly due to the paste-aggregate interface transition zone which is better, from the mechanical point of view, for crushed aggregates. In the case of limestone aggregates, the reaction between $\mathrm{CaCO}_{3}$ and $\mathrm{C}_{3} \mathrm{~A}$ and $\mathrm{C}_{4} \mathrm{AF}$ gives calcium aluminate monocarbonate $\mathrm{C}_{3} \mathrm{~A} \cdot \mathrm{CaCO}_{3} \cdot \mathrm{H}_{11}$ which accelerates the hydration of calcium silicates [31]. Following the formation of $\mathrm{C}_{3} \mathrm{~A} \cdot \mathrm{CaCO}_{3} \cdot \mathrm{H}_{11}$ at the paste-aggregate interface, the bond becomes weakly porous and consequently, the mechanical strength increases [32]. However, in the case of silica aggregates, the interface transition zone which appears during hydration is highly porous and thus less resistant than the paste itself [33]. 


\subsection{Influence of temperature}

The results obtained with PSC-s, PPC-s and PSC-c show that degradation due to external sulfate attack is faster at low temperatures. This sensitivity to low temperatures can be attributed to the atmospheric carbonation which increases the amount of carbon dioxide dissolved in the pore solution which is to be loaded with large amounts of carbonates [34]. These are indispensable sources for the formation of thaumasite (TSA) [17]. However, the formation of thaumasite was probably facilitated by ettringite-induced cracking [35]. The samples exposed to external sulfate attacks at $20,50{ }^{\circ} \mathrm{C}$ showed no degradation, can be attributed to two types of reactions. On the one hand, the hydration of cement continues to occur, in addition to slag and pozzolan which produce secondary C-S-H, they promote densification, and lower permeability. On the other hand, the reaction of sulfate ions with cement hydrates gives gypsum, brucite and secondary ettringite. Both reactions lead, after 12 months, to a denser structure which improves the aggregatepaste interface.

One can assert that the attack of cementitious materials by sulfates at high temperature is much slower than that low temperature.

\subsection{Influence of cement}

PSC samples show a lower resistance against external sulfate attacks (ESA); it is followed by PPC at $5{ }^{\circ} \mathrm{C}$. These two types of cement are of the same strength class 42.5 and contain additions that trigger pozzolan reactions, but have different behaviors. They also contain different proportions of $\mathrm{SiO}_{2}$ and $\mathrm{CaO}$, which shows that $\mathrm{CaO} / \mathrm{SiO}_{2}$ ratios are greater for PPC than for PSC. The lower this ratio, the more secondary C-S-H is formed by pozzolanic reactions, and the better behavior mortar shows against external sulfate attacks (ESA) [21]. Moreover, SRPC cement, containing silica sand, showed some degradation on the corners, after 12 months of immersion in sulfate solution at $5{ }^{\circ} \mathrm{C}$, which indicates that a low content of $\mathrm{C}_{3} \mathrm{~A}$ does not prevent the degradation caused by the thaumasite formed, because in this case, calcium silicate hydrates are also attacked.

\section{Conclusion}

The following conclusions can be drawn from this study:

- No damage is observed on samples exposed to the sulfate solution, for a period of 12 months, at 20, and $50{ }^{\circ} \mathrm{C}$.

- Magnesium sulphate attacks at low temperatures are much faster than those in 20 , and $50{ }^{\circ} \mathrm{C}$.

- Mortars with limestone sand show better resistance to sulphate attacks compared to those containing silica sand which have a more porous interfacial transition zone (ITZ).

- The attack mechanism of cement hydrates by magnesium sulfates varies from one type of mortar to another; it depends on the nature of cement as well as on its chemical composition $\left(\mathrm{Ca}(\mathrm{OH})_{2}\right.$ content and $\mathrm{CaO} / \mathrm{SiO}_{2}$ ration), type of sand used, $\mathrm{pH}$ and temperature of solution.

- XRD analysis indicates that Ettringite, thaumasite and gypsum are the main products causing the deterioration of cementitious materials.

- Cements with low $\mathrm{C}_{3} \mathrm{~A}$ content are subject to degradation caused by the thaumasite formed (TSA).

- The test results show that the ultrasonic velocity gives information about the internal micro-cracking of the specimen and provides evidence of damage mortar.

\section{Acknowledgements}

The authorswould like to acknowledge the financial backing of DGRSDT through the PNR project Dubem 16-35 who financially supported this research.

This is an Open Access article distributed under the terms of the Creative Commons Attribution Licence

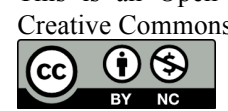

\section{References}

[1] A. Leemann, R. Loser, Analysis of concrete in a vertical ventilation shaft exposed to sulfate-containing groundwater for 45 years, Cement and Concrete Composites 33(1) (2011) 74-83.

[2] M. Whittaker, L. Black, Current knowledge of external sulfate attack, Advances in Cement Research 27(9) (2015) 532-545.

[3] P.K. Mehta, P.J.M. Monteiro, CONCRETE: Microstructure, Properties and Materials, McGraww Hill2006.

[4] M.J.O.I. Skalny J, Sulfate attack on concrete (Modern ConcreteTechnology), Spon Press2002.

[5] F.A.O, DISTRIBUTION OF GYPSIFEROUS SOILS BY COUNTRIES, [ [ consulted $04 / 21 / 2016$ http://www.fao.org/docrep/t0323e/t0323e02.htm\#1.4 Classification of Gypsiferous Soils, .).

[6] M. Bederina, Z. Makhloufi, A. Bounoua, T. Bouziani, M. Quéneudec, Effect of partial and total replacement of siliceous river sand with limestone crushed sand on the durability of mortars exposed to chemical solutions, Construction and Building Materials 47 (2013) 146-158.

[7] E.F. Irassar, Sulfate attack on cementitious materials containing limestone filler - A review, Cement and Concrete Research 39(3) (2009) 241-254.

[8] M. Ghrici, S. Kenai, M. Said-Mansour, Mechanical properties and durability of mortar and concrete containing natural pozzolana and limestone blended cements, Cement and Concrete Composites 29(7) (2007) 542-549.
[9] O.S.B. Al-Amoudi, Sulfate attack and reinforcement corrosion in plain and blended cements exposed to sulfate environments, Building and Environment 33(1) (1998) 53-61.

[10] S.T. Lee, H.Y. Moon, R.N. Swamy, Sulfate attack and role of silica fume in resisting strength loss, Cement and Concrete Composites 27(1) (2005) 65-76.

[11] E. Ganjian, H.S. Pouya, Effect of magnesium and sulfate ions on durability of silica fume blended mixes exposed to the seawater tidal zone, Cement and Concrete Research 35(7) (2005) 1332-1343.

[12] A. Skaropoulou, K. Sotiriadis, G. Kakali, S. Tsivilis, Use of mineral admixtures to improve the resistance of limestone cement concrete against thaumasite form of sulfate attack, Cement and Concrete Composites (0) (2013) -

[13] A.M. Hossack, M.D.A. Thomas, Evaluation of the effect of tricalcium aluminate content on the severity of sulfate attack in Portland cement and Portland limestone cement mortars, Cement and Concrete Composites 56 (2015) 115-120.

[14] F. Aköz, F. Türker, S. Koral, N. Yüzer, Effects of raised temperature of sulfate solutions on the sulfate resistance of mortars with and without silica fume, Cement and Concrete Research 29(4) (1999) 537-544.

[15] M. Santhanam, M.D. Cohen, J. Olek, Modeling the effects of solution temperature and concentration during sulfate attack on cement mortars, Cement and Concrete Research 32(4) (2002) 585592. 
[16] K. Tosun-Felekoglu, The effect of C3A content on sulfate durability of Portland limestone cement mortars, Construction and Building Materials 36(0) (2012) 437-447.

[17] G. Collett, N.J. Crammond, R.N. Swamy, J.H. Sharp, The role of carbon dioxide in the formation of thaumasite, Cement and Concrete Research 34(9) (2004) 1599-1612.

[18] K. Wu, H. Shi, L. Xu, G. Ye, G. De Schutter, Microstructural characterization of ITZ in blended cement concretes and its relation to transport properties, Cement and Concrete Research 79 (2016) 243-256.

[19] P. Nielsen, S. Nicolai, A. Darimont, X. Kestemont, Influence of cement and aggregate type on thaumasite formation in concrete, Cement and Concrete Composites 53 (2014) 115-126.

[20] X. Brunetaud, M.-R. Khelifa, M. Al-Mukhtar, Size effect of concrete samples on the kinetics of external sulfate attack, Cement and Concrete Composites 34(3) (2012) 370-376.

[21] Z. Makhloufi, S. Aggoun, B. Benabed, E.H. Kadri, M.Bederina, Effect of magnesium sulfate on the durability of limestone mortars based on quaternary blended cements, Cement and Concrete Composites 65 (2016) 186-199.

[22] Z. Liu, D. Deng, G.D. Schutter, Z. Yu, The effect of MgSO4 on thaumasite formation, Cement and Concrete Composites 35(1) (2013) 102-108.

[23] H.T. Cao, L. Bucea, A. Ray, S. Yozghatlian, The effect of cement composition and $\mathrm{pH}$ of environment on sulfate resistance of Portland cements and blended cements, Cement and Concrete Composites 19(2) (1997) 161-171.

[24] R. El-Hachem, E. Rozière, F. Grondin, A. Loukili, New procedure to investigate external sulphate attack on cementitious materials, Cement and Concrete Composites 34(3) (2012) 357-364.

[25] B.M. Bellmann. F , Stark .J, Influence of sulfate solution concentration on the formation of gypsum in sulfate resistance test specimen, Cement and Concrete Research 36(2) (2006) 358-363.
[26] B. Tian, M.D. Cohen, Does gypsum formation during sulfate attack on concrete lead to expansion?, Cement and Concrete Research 30(1) (2000) 117-123.

[27] M.B. Tixier. R, Modeling of damage in cement-based materials subjected to external sulphate attack. I: formulation,, J. Mater. Civ. Eng 15(4) (2003) 305-313.

[28] D. Heinz, L. Urbonas, About thaumasite formation in Portlandlimestone cement pastes and mortars - effect of heat treatment at 95 ${ }^{\circ} \mathrm{C}$ and storage at $5{ }^{\circ} \mathrm{C}$, Cement and Concrete Composites $25(8)$ (2003) 961-967.

[29] E.F. Irassar, V.L. Bonavetti, M.A. Trezza, M.A. González, Thaumasite formation in limestone filler cements exposed to sodium sulphate solution at $20{ }^{\circ} \mathrm{C}$, Cement and Concrete Composites 27(1) (2005) 77-84.

[30] J. Bensted, Thaumasite - direct, woodfordite and other possible formation routes, Cement and Concrete Composites 25(8) (2003) 873-877.

[31] G. Kakali, S. Tsivilis, E. Aggeli, M. Bati, Hydration products of $\mathrm{C} 3 \mathrm{~A}, \mathrm{C} 3 \mathrm{~S}$ and Portland cement in the presence of $\mathrm{CaCO}$, Cement and Concrete Research 30(7) (2000) 1073-1077.

[32] I. Gaweska Hager, Comportement à haute température des bétons à haute performance - évolution des principales propriétés mécaniques, l'Ecole Nationale des Ponts et Chaussées etl'Ecole Polytechnique de Cracovie, 2004.

[33] Y. Malier, Les Béton à hautes performance - Caractérisation, durabilité, applications, Presses de l'Ecole Nationale des Ponts et Chaussées (1992) 674-674.

[34] J. Bensted, Thaumasite - background and nature in deterioration of cements, mortars and concretes, Cement and Concrete Composites 21(2) (1999) 117-121.

[35] T. Schmidt, B. Lothenbach, M. Romer, J.r. Neuenschwander, K. Scrivener, Physical and microstructural aspects of sulfate attack on ordinary and limestone blended Portland cements, Cement and Concrete Research 39(12) (2009) 1111-1121. 